Internationales Asienforum, Vol. 30 (1999), No. 1-2, p. 5-26

\title{
Radical Islam, Jihad and Civil War in Afghanistan
}

\author{
HAFIZULLAH EMADI*
}

Can wine distilled from poison escape being poisonous? Can art distilled in an era of evil escape being pernicious? Can politics created out of an era of evil escape its evil tactics?

M.J. Fischer's rendition of Sadeq Hedayat's The Blind Owl

\section{Introduction}

The last decades of the twentieth century have been depicted as an era of resurgence of the Islamic movement, or Jihad as evidenced in academic discourse, diplomatic parlance and the international media. The word Jihad, which means struggle, has been used to signify a new socio-political awakening within the Muslim world. Jihad as conducted by Muslims today cannot be fully comprehended without taking into consideration the internationalization of the capitalist world system and the subjugation of the Muslim world. The rise of Islamic insurgency in a single Islamic society must be viewed as a counter-strategy to international stratification of power.

The Islamic doctrine and its ethical systems have always been subject to progressive, innovative and radical interpretations as well as to the most regressive, orthodox and fundamentalist renditions. Muslim scholars and intellectuals of the first category did not view Islam as antithetical to progress and modernity; they supported innovative and critical thinking as a sine qua non to development in the Muslim world and deplored the international structure of power. One such Muslim intellectual, Sayed Jamal alDin al-Afghani (d. 1896) was an eminent Islamic revivalist who was con-

\footnotetext{
* The author would like to express his heartfelt gratitude to Mohamed Alibhai, a valued friend and mentor in Islamic Studies, and to the editorial board of Internationales Asienforum for their comments on an earlier version of this article.

1 Cited in Farideh Farhi, States and Urban-Based Revolutions (Urbana: University of Illinois Press, 1990), p. 106.
} 
cerned with the decline of the Muslims and the rise of Western imperial powers. He believed that the failure of the Muslims could be perceived in their disunity in thinking as well as in their action ${ }^{2}$, and began to lecture on Islamic unity, the resurrection of Islamic art, philosophy and independence of Islamic societies. His lectures had a lasting impact on Muslim intellectuals at the turn of the century to resist and oppose the British colonial empire. The well known Pakistani poet and scholar Muhammad Iqbal (1876-1938) was another important figure within the revivalist movement who defied the unbridled exploitative nature of capitalism. He did not oppose modernity but rather applauded modernizers within the Muslim and non-Muslim world, evidenced in his poems to Lenin, the leader of the Bolshevik revolution in Russia and in his anthology Payam-e-Mashriq to King Amanullah of Afghanistan. ${ }^{3}$

While the ruling elites in the Muslim world remained subordinate to the colonial and imperial powers and were concerned with protecting their vested class interest, religious oriented elites of middle class backgrounds began to articulate a radical change of the status quo. Their articulation for change is based on a call to return to the legacy of pristine Islam. In the immediate post World War II period prominent Sunni elites, such as Sayed Qutb (1906-1964) and Hasan al-Bana (1906-1949) in the Middle East and Abu al-Ala Mawdudi in the Indian subcontinent (1903-1979), postulated that a return to Islamic law (Sharia) is the only viable road to Islamic salvation. ${ }^{4}$ Similarly the works of Shiite clerics and intellectuals such as Ayatollah Rohallah Khomeini and Ali Shariati in Iran contributed to the radicalization of the middle classes in the Muslim world. ${ }^{5}$

The failure of Islamists can be attributed to the inability of their leaders to reconcile their ideological and philosophical differences and work toward creating opportunities for innovative encounters among various ethno-linguistic communities within the Muslim world to help people unite in a common struggle against external domination and exploitation. This study attempts to examine the resurgence of radical Islam in the immediate post-World War II period in Afghanistan when both the United States and the Soviet Union competed for political domination and hegemony, explores the extent of Islamic encounters with imperial cultural and political

2 Anwar Moazzam, Jamal al-Din al-Afghani: A Muslim Intellectual (New Delhi: Concept, 1984)

3 Iqbal, Muhammad, Kuliyat-e-Iqbal (Lahore: Sheikh Ghulam Ali \& Sons, 1973), pp. 185-86; 379

4 Sayed Ali Reza Nasr, Mawdudi and the Making of Islamic Revivalism (New York \& Oxford: Oxford University Press, 1996)

5 Habib Shirazi (tr.) Ali Shariati's Red Shiism (Tehran: The Shariati Foundation, 1979); Ervand Abrahimian, Khomeinism: Essays on the Islamic Republic (Berkeley: University of California Press, 1993) 
influence and their role during the national liberation struggle when the invading Soviet army occupied the country (December 1979 -February 1989) and studies how the Jihad has been transformed into an ethnic war in the immediate post-Soviet era.

\section{The Clergy and King Amanullah, the Modernizer}

When Afghanistan gained its independence from the British in 1919, Amanullah began to modernize the country on the basis of a European model of development. Amanullah was impressed by technological developments in the West and tried to transform the backward socio-economic structure of the country by initiating radical reforms. His modernization strategies were based on the principles of secularism where religion is separated from politics and the state. He promulgated a new constitution which accorded equal rights to every citizen of the country. Amanullah fought for gender equality, campaigned for the advancement of the cause of women and sent a few women abroad for higher education. In the process he restricted the power of feudal landowners, some of whom were in charge of religious affairs in various parts of the country. To regain their leading position the clerics and tribal chiefs began to instigate public uprisings against Amanullah, claiming that he had violated Islamic principles of governance and called for a Jihad as the necessary means to restore Islamic traditions.

The resistance to Amanullah in Kabul was lead by Habibullah known as bacha-e-saqaw (water carrier son). Amanullah was forced to leave Kabul for Qandahar where he organized an army to regain the capital, Kabul. When his army was defeated Amanullah abdicated the throne and left the country for Italy. Habibullah seized power in 1929 and ruled for nine months. ${ }^{6} \mathrm{He}$ came from an underprivileged social background. His father, Hamidullah, delivered water to the Afghanistani freedom fighters during the second Anglo-Afghan war in 1878-80. He symbolized the aspiration and dismay of the uneducated over Amanullah's radical modernization, and prior to assuming power he was known as a Robin Hood-like bandit who robbed the rich to help the poor. ${ }^{7}$ Habibullah was hailed by conservative clerics and his supporters, and awarded the title of Khadim-e-dini Rasulullah (Servant

6 Hafizullah Emadi, State, Revolution and Superpowers in Afghanistan (New York: Praeger Publishers, 1990), p. 5; 2nd Edition (Karachi: Royal Book Company, 1997)

7 Sayed Rasul, Nigahi ba Ahdi Saltanat-e-Amanullah [A glance at the Amanullah's era] (n.p: 1984) 
of the Prophet). The British government supported anti-Amanullah insurgency on the grounds that he was bent on lending support to the anti-colonial movement in British-controlled India. Habibullah was an illiterate man and had no experience in administration. During his nine-month rule he abolished all progressive socio-economic development projects initiated by Amanullah and closed down schools for girls. An illiterate Tajik ruler, Habibullah was unable to gain the allegiance of other tribal communities, particularly the Pushtuns who ruled the country for hundreds of years. Believing that only a man of nobility is entitled to divine leadership, tribal communities would not support the leadership of a man who came from among commoners. To transform this public perception and consolidate his rule Habibullah published a newspaper, Habib al-Islam (Friend of Muslims). One of the issues of the paper started a public relations campaign to convince the public that leadership is not hereditary and anyone dedicated to service of the people, regardless of his social status, can lead the community. He referred to Henry, the well known British monarch who was a bandit prior to becoming a king, as an example of such leadership. ${ }^{8}$

The British government, convinced that Habibullah could not effectively consolidate his rule and protect British interests in Afghanistan, supported General Mohammad Nadir to mobilize his Pushtun tribes of Paktiya province in a bid to seize power. Nadir launched a major assault on Habibullah and drove him out of Kabul. Habibullah fled to the safety of his hometown, Kohdaman, and began to regroup his forces for capturing Kabul. Nadir tried to persuade him to give up his arms and return to Kabul. He wrote a note in the margin of the Quran to the effect that he promised not to do him any harm if he returned to Kabul. He signed the note, put his seal on it and send it to Habibullah who naively accepted the offer and returned to Kabul where he was captured and summarily executed. (Rising Islamic zeal in the 1980s led a number of writers to regard Habibullah as a martyred Muslim hero who dedicated himself to the cause of Islam). ${ }^{9}$

In October 1929 Nadir seized power, declared himself king and was portrayed as the liberator of Afghanistan by his supporters. In 1930 he convened a grand assembly of tribal chiefs to endorse a new constitution and confirm him as the new king. To garner support among clerics Nadir established the Jamiat-e-Ulama-e-Islami (Society of Islamic Scholars) and lifted restrictions and limitations on political, social, judicial and education work that Amanullah had placed upon clerics. He appointed Pushtuns and Pushtunized elites as administrators in non-Pushtun areas to reward them

8 op.cit., pp. 283-84

9 Shah Agha Mojaddadi, Amir Habibullah (Lahore: Abdul Hamid Al-Jida, 1980); Khalilullah Khalili, Ayari az Khurasan (Peshwar: n.p., 1983) 
for their support during his war on Habibullah and pursued communal politics by pitting one ethnic group against the other in order to maintain his rule. Nadir eliminated his opponents and ruled the country singlehandedly. His short rule ended when Hazara intellectual, Abdul Khaliq, assassinated him in Kabul in 1934. Nadir was succeeded by his son Mohammad Zahir, who ruled the country until $1973 .^{10}$

\section{The State and Radical Islam in the post-World War II Period}

King Zahir continued his father's domestic policy orientation. He was anxious not to antagonize conservatives, and forged alliances with clerics and feudal landowners. Although his government embarked upon modernization of the country, capitalist development from the top did not significantly alter the basis of the traditional economy, culture and politics nor did it succeed in improving the impoverished conditions of the dispossessed strata. While rising unemployment, sky-rocketing of the prices of consumer goods and rampant poverty crippled the country, Zahir enriched himself by skimming off wealth from Afghanistan financial centers and trading companies to his overseas bank accounts. When his finance minister, Abdul Malik Abdurahimzai registered Zahir's overseas financial assets as Afghanistan's national asset, he and his secretary, Ali Asghar Shua, were jailed. Zahir did not put Abdurahimzai on trial, fearing that it would expose the corruption of the ruling family. ${ }^{11}$ The deteriorating economy and declining standards of living coupled, with administrative corruption and nepotism, generated sympathy for radical socialist ideas among blue and white collar workers and students. It was during this period that radical Islam emerged to counterbalance the spreading influence of these ideas.

Two major religio-political trends began to gain currency within the antistate opposition movement; radical Shiism and the Sunni-dominated movement known as Eikhwan al-Muslimin (Islamic Brotherhood). The Shiites were greatly influenced by the political and social philosophies of Ayatollahs such as Abd al-Qasim Khoyi of Iraq and Ruhallah Khomeini of Iran. ${ }^{12}$ A Cleric such as Esmail Balkhi who studied in Mashhad, Iran, and Najaf in Iraq began to instill new religious awareness among the Shiites upon his

10 Hafizullah Emadi, State, Revolution and Superpowers in Afghanistan

11 Talib Mohammad Husain Qandahari, Nigai ba Diroz wa Emroz-e-Afghanistan [A glance at the past and present of Afghanistan] (n.p.: 1362/1983), p. 36

12 Hafizullah Emadi, "Exporting Iran's Revolution: The Radicalization of the Shiite Movements in Afghanistan", Middle Eastern Studies 31:1 (January 1995), pp.1-12 
return to Afghanistan in the 1950s. He and his close associates were imprisoned on charges that they were planning to overthrow the government by a coup. Balkhi was sentenced to 15 years imprisonment. On his release from prison he visited Iraq and Iran and upon his return home he died of a mysterious illness in 1347/1963. His followers claim that he was murdered by the regime. At present the highest ranking clerics within the Shiite hierarchy in Afghanistan is Qurban Ali Muhaqiq of Turkman valley, Parwan province, and Taqadusi, who was a staunch follower of Khomeini and one of the founders of Sepah-e-pasdaran (revolutionary guards). ${ }^{13}$

Educated elites of the Sunni tradition such as Ghulam Mohammed Niazi, Burhanuddin Rabbani, Abdurab Rasul Sayaf, and Mohammad Musa Tawana who studied at Al-Azhar University in Egypt were under the ideological influence of Sayed Qutb and Hasan al-Bana, founders of Eikhwan al-Muslimin movement in Egypt. When they returned home they began to propagate the political philosophy of their Egyptian mentors in Afghanistan schools and colleges. There was no officially established Islamic organization as such in the early 1960s, but radical Islam spread with the publication of newspapers and periodicals such as Gahiz (Morning), Nedae-Haq (Voice of Truth), and Afkar-e-Naw (New Thought) through which advocates of Islamic ideology could express their views. ${ }^{14}$ Further spread of radical Islam finally culminated in the formation of Jamiat-e-Islami (Islamic Society) in 1343/1967 as a reaction to communist activities. ${ }^{15}$ The movement gained the reputation of Eikhwan al-Muslimin within the Afghanistani radical anti-establishment movement. Niazi, dean of the college of Islamic Studies at Kabul University, was chairman of the organization. He was detained and sentenced to life imprisonment in 1974 during the reign of President Mohammad Daoud (1973-1978) and was murdered when Afghanistan was declared a democratic republic in April 1978. After Niazi's arrest members of the organization elected Burhanuddin Rabbani head of the organization.

The Islamists began recruiting supporters by organizing meetings, rallies and public forums in schools and colleges at the campus of Kabul University. They opposed women's public activities and during a women's rally in Kabul in 1969, a man from Herat province, Gul Mohammad, threw acid on

13 Hafizullah Emadi, "The Hazaras and their Role in the Process of Political Transformation in Afghanistan", Central Asian Survey 16:3 (1997), pp. 363-387

14 Hafizullah Emadi, Afghanistan's Gordian Knot: An Analysis of National Conflict and Strategies for Peace (Honolulu: East-West Center, 1991); 2nd Edition, (Karachi: Royal Book Company, 1997)

15 M. Zaman Muzammil, Reasons for the Russian Occupation and Dimensions of the Resistance in Afghanistan (Peshawar: Hizb-e-Islami Afghanistan, 1979), p. 16 
several schoolgirls, severely wounding them. When he was arrested he said that he would do it again if he was released. ${ }^{16}$ The Islamists also opposed and fought supporters of the leftist organizations. During a bitter ideological debate that arose between the Islamists and supporters of the pro-Beijing Sazman-e-Javana-e-Mutarqi (Progressive Youth Organization) known as Shula-e-Jawid (Eternal Flame) on the campus of Kabul University in June 1972, a bloody fight broke out which resulted in the death of Saidal Sukhandan, a well known member of the organization, and the injury of numerous others. ${ }^{17}$ Shortly after this incident the editor of Gahiz, Minhajuddin Gahiz was murdered at his home ${ }^{18}$, which led the Islamists to believe that supporters of Shula-e-Jawid had committed this act to avenge the death of Saidal, but a member of Jamiat-e-Islami blamed the Russians for the murder of Saidal, arguing that they viewed it as an opportunity to incite the radical Islam and Shula-e-Jawid to go to war with each other. ${ }^{19}$ Power struggles within the organization led to a split and a new organization, Hizb-e-Islami (Islamic Party) emerged under the leadership of Gulbuddin Hikmatyar, then a student at the College of Engineering, Kabul University.

\section{The Republican Regime and Radical Islam}

In 1973 the monarchy was overthrown and former Premier Mohammad Daoud proclaimed Afghanistan a republic. Daoud was supported by the pro-Soviet Parcham faction of Hizb-e-Demokratiki Khalq-e-Afghanistan (People's Democratic Party of Afghanistan, PDPA) and began to hunt down members of two radical movements, Shula-e-Jawid and the Islamists. ${ }^{20}$ To consolidate his power base Daoud had other influential personalities such as former premier Mohammad Hashim Maiwandwal and a well-known merchant, Mohammad Arif, alias Rikshaw (he imported Pakistani-made tricycles for use as mini cubs) put to death, imprisoned former

16 Hafizullah Emadi, Politics of Development and Women in Afghanistan (New York: Paragon House Publishers, 1993), p. 70. Second edition (Karachi: Royal Book Company, 1997)

17 Akhgar (Sazman-e-tadaruk Bara-e-Eijadi Hizb-e-kamunist dar Afghanistan), Afghanistan (Tehran, 1980), p.28

18 Haqshinas, Dasayis wa Jinayat-e-Rus dar Afghanistan: Az Amir Dost Mohammad Khan ta Babrak [Russian ploys and criminal activities in Afghanistan from Amir Dost Mohammad Khan period to that of Babrak Karmal] (Tehran: Cultural Committee of the Central office of Jamiat-e-Islami, 1363/1984), p. 336

19 Hafizullah Emadi, State, Revolution and Superpowers in Afghanistan

20 Hafizullah Emadi, "China's Politics and Developments in Afghanistan", Journal of Asian and African Studies 28:1\&2 (January-April 1993), pp. 107-117; for details see, Hafizullah Emadi, China's Foreign Policy Toward the Middle East (Karachi: Royal Book Company, 1997) 
premier Mohammad Musa Shafiq and his associates, and nationalized the properties of another merchant, Hazargul. ${ }^{21}$

The liberals and radical Islam regarded Daoud's pro-Soviet policy as a threat to their interests and decided to fight the regime. Supported by Pakistan, a number of Islamists, including Ahmad Shah Masoud, launched a major assault on various government installations in Panjshir, Herat, and Laghman provinces. ${ }^{22}$ Pakistan and the Islamists were not in a position to overthrow the regime in Kabul; their main goal was to warn Daoud that such anti-state activities would continue if he did not abandon his socialistoriented policies and support for autonomy for Pushtuns and Baluchis residing on the Pakistani side of the Durand Line. ${ }^{23}$ When the Islamists suffered a fatal blow by Daoud's military offensive they went underground and their leaders remained in Pakistan until the establishment of the democratic regime in April 1978.

\section{The Democratic Republic and Radical Islam}

Daoud was overthrown by army officers loyal to the Khalq faction of the PDPA and Afghanistan was declared a democratic republic in April 1978 with Noor Mohammad Taraki, chairman of the PDPA, as head of state. The new regime embarked upon a plethora of radical reforms intended to transform the country's backward economy patterned on the Soviet model of development. The socio-economic reforms (decree no. 6 regarding reduction of loans and mortgages, decree no. 7 on women's emancipation and decree no. 8 on land reform) by the pro-Soviet regime antagonized landowners, industrialists and big businessmen, and caused them to flee the country. Sovietization of the country's politics and culture, particularly the state policy of promoting gender equality and socialist morality, antagonized traditionally entrenched feudal and religious leaders. ${ }^{24}$ Implementation of the decrees was carried out with coercion and those who resisted or opposed the reform were detained, tortured and even murdered. Political repression and coercion compelled people of various social and political backgrounds to fight the regime. When the spontaneous rebellion against

\footnotetext{
21 Hafizullah Emadi, State, Revolution and Superpowers in Afghanistan, p. 66

22 Abdul Hafiz Mansur, Panjshir dar Dawran-e-Jihad [Panjshir during the Jihad era] (n.p: $1369 / 1990)$, p. 28

23 Jaraqa (Urgan-e-tiyuriki Eitihadi Marksist-Lininista-e-Afghanistan or Theoretical Organ of the Union of Marxist-Leninists of Afghanistan), 2 (September 1985), p. 2 Hafizullah Emadi, Politics of Development and Women in Afghanistan
} 
the regime escalated, Islamists in exile in Pakistan received substantial aid from the Middle East and Western countries and the Shiite organizations, encouraged by clerics in Iran, received political, economic and military support from them when they seized power in Iran in early $1979 .{ }^{25}$

When resistance to the regime escalated throughout the country, Kabul accused Iran, Pakistan, Saudi Arabia and the United States of interfering in their internal affairs. The state declared war on what it called foreign agents, stating that in " $1357 / 1978$ the people of Afghanistan declared a jihad against (priests), clerics and Ekhwanis made in London and Paris and all our toiling Muslim people expressed hatred against them." ${ }^{26}$ The escalation of anti-regime armed struggle on the one hand and interparty struggle between the Khalq and Parcham factions of the ruling party on the other, compelled the Soviet leadership to remove Premier Hafizullah Amin, who was considered to be the main source of all the troubles. When Taraki returned from a trip to Cuba and Moscow he summoned Amin to the palace (Peoples' House) for a meeting where a fight broke out between supporters of Taraki and Amin which resulted in the death of the former and ascension to power by the latter. Soon after, the central committee of the party convened a meeting which elected Amin president of the country.

Amin began to consolidate his position by demoting supporters of Taraki from key state and party positions and made overtures to the West, maintaining that the new leadership in Kabul was prepared to normalize its relations with them. The Soviet Union was not happy with the new development, not wanting to see Afghanistan slip away from its sphere of influence, and decided to intervene militarily to alter the course of events in the country. In December 1979 the Soviets deployed a contingent of their armed forces to Kabul on the pretext of defending the country against the escalating anti-regime insurgency and in the process they eliminated Amin and installed Babrak Karmal as the new head of state.

\section{The Soviet Occupation and the Jihad}

The Soviet invasion and occupation enraged public opinion and caused a great number of the Afghanistani people to fight for liberation of their homeland. To consolidate the regime the Soviet-backed government began

25 "U.S. Aid to Afghan Rebels is Largest Covert Operation since Era of Vietnam War", The Washington Post, 20 January 1985, pp. 15-17

26 Afghanistan, Democratic Republic of Afghanistan's Annual (Kabul: Government Printing House, 1979), p. 356 
to arrest those suspected of anti-regime activities. This situation forced many of the traditional ruling elites, influential aristocratic families, and traditional religious leaders (also big landowners) to seek refuge in Pakistan. Spontaneous public uprisings began with various motivations, but there was not a nationally based organization to unite and lead the uprising. This situation provided an opportunity to leaders of Islamic parties, who had already established themselves in Pakistan, to seize leadership of the resistance. As the uprising continued throughout the country and the pro-Soviet regime intensified its efforts to eliminate opposition figures, more clerics left the country for Pakistan and began organizing their supporters. The number of Islamic parties mushroomed in Peshawar, Pakistan. The well organized ones include the following ${ }^{27}$ :

- Hizb-e-Islami (Islamic Party)

Head: Gulbuddin Hikmatyar

Ideology: Islamic Fundamentalism

Composition: 2,500 staff, 20,000 partisans.

Main Front Commanders: Farid, Kapisa and Parwan provinces; Mahmood, Nangarhar province (switched loyalty to Hizb-e-Islami led by Khalis, 1986); Abdul Ghayour, Baghlan province; Laghman province, commander unnamed

- Hizb-e-Islami (Islamic Party), a breakaway faction of Hikmatyar's Islamic Party

Head: Mohammad Yunus Khalis

Ideology: Islamic Fundamentalism

Composition: 2,500 staff, 17,000 partisans

Main Front Commanders: Jalaluddin Haqqani, Paktiya province; Abdul Haq, Kabul province; Abdul Qadir, Nangarhar province; Qari Samad (killed in 1985), Logar province; Mullah Malang, Qandahar province

- Jamiat-e-Islami (Islamic Society)

Head: Burhanuddin Rabbani

Ideology: Islamic Fundamentalism

Composition: 5,000 staff, 30,000 partisans

Main Front Commanders: Ahmad Shah Masoud, Panjsher valley; Ismail

Khan, Herat, Farah and Badghish provinces; Zabiullah Khan (killed, 1984), Balkh and Samangan provinces

27 Adapted from Mark Urban, War in Afghanistan (New York: The Macmillan Press, 2nd ed. 1990), pp. 328-330; US Department of State Bulletin, March 1988, p. 8 
- Mahazi-e-Islami (National Islamic Front)

Head: Sayed Ahmad Gaillani

Ideology: Conservative Islam

Composition: 2,500 staff, 18,000 partisans

Main Front Commanders: Amin Wardak, Wardak province (switched loyalty to Hizb-e-Islami led by Khalis, 1988); Abdul Latif, Qandahar province; Rahmatullah Safi, Paktiya province; Zaman, Nangarhar province

- Jabha-e-Milli-e-Nijat (National Liberation Front)

Head: Sebghatullah Mujaddadi

Ideology: Conservative, pro-establishment

Composition: 1,500 staff, 3,500 partisans

Main Front Commanders: Mohammad Zarin, Kunar province; Abdul Bashir, Helmand province

- Harakat-e-Enqilabi Islami (Islamic Revolutionary Movement)

Head: Nabi Mohammadi

Ideology: Conservative

Composition: 2,000 staff, 20,000 partisans

Main Front Commanders: Sayed Murtaza, Logar province; Mohammad Shah, Farah province; Shafiullah (killed, 1985), Kho-e-Safi district; Qari Taj Moahmmad, Ghazni province; Mohammad Nasim Akhundzada, Helmand province.

- Ittehadi Islam-e-Mujahidin (Islamic Unity of Mujahidin)

Head: Abdur Rabb Rasoul Sayaf

Ideology: Wahabism

Composition: 900 staff, 4,000 partisans

Main Front Commanders: Abdul Hay, Qandahar province; commanders of Kabul and Paktiya provinces unnamed

Although these parties maintained their independent organizational structures, ideologically they can be classified into two main groups: a) radicals and b) moderates. The first group is comprised of Hikmatyar's Hizb-eIslami, Rabbani's Jamiat-e-Islami, and Yunus Khalis's Hizb-e-Islami (an offshoot of Hikmatyar's party with the same nomenclature). The main ideological thrust of this group is the propagation of Islamic orthodoxy and orthopraxy and the establishment of a theocratic state under the guidance of a religious leader (amir). According to their interpretation state and 
society are the same and a true Islamic society is governed by God's law. Hikmatyar stated his party's position regarding the future of Afghanistan as follows:

"Democracy and Islam do not go together; that is a very un-Islamic state. Afghanistan will be a strict Islamic state. A group of wise men will adapt the laws to Islam. ... All alcohol will be banned, women will stay at home once again, and the mullahs will have more power."28

Unlike the traditionalists who maintain that leaders of the Muslim parties must come from among Ulamas (religious scholars), political Islam argues that this is not necessarily so. Any person who has a good knowledge of Islamic law and exhibits ethical qualities based on the Islamic ethos can lead the Islamic community. State, according to political Islam, is nothing but a committee of men working together as servants of God. In a similar vein, albeit in a slightly moderate version, Jamiat-e-Islami expressed its position regarding the building of an Islamic state as follows:

"Establishment of [an] Islamic system forms our main obligation and our sacred aim. ... Jamiat wants to improve relations between the owner of the land and farmer employer and employee in such a way that instead of fighting against each other they live in a cooperative atmosphere.,"29

Leaders of the moderate Islamic groups come from traditional Islam. The moderates do not attach much importance to political organization as a strategy for building an Islamic society. The efforts of the Soviet-backed regime in Kabul to repair mosques and build new ones for the purpose of expanding its social base made some progress in securing the support of a number of Afghanistanis and caused the moderates to gradually distance themselves from Islamic orthodoxy as a driving force for anti-Soviet resistance. The moderates echoed nationalism and capitalized on issues such as "freedom of speech", "democracy", etc., in order to rally liberals, democrats and nationalist forces to their side.

Sayed Ahmad Gaillani, Sebghatullah Mujaddadi, and Mohammad Nabi Mohammadi are the leading personalities among the moderates who regard resistance as a Jihad, but they emphasize the secular character of the resistance, claiming that it fights for an independent Afghanistan. Gaillani, an urban businessman until the Soviet invasion, was the Peugeot representative in Kabul. He has a significant number of followers among the Pushtuns and remained on good terms with the ruling elites prior to the establishment of the pro-Soviet regime in Kabul.

28 FBIS, Middle East and North Africa Daily Report 6 March, 1980. p. 2

29 "Aims and Goals of Jamiat-e-Islami-e-Afghanistan", Mirror of Jihad 1 (January-February 1982), pp. 10-11 
"His family's inter-marriage with the ruling Kabul elites, his personal wealth, and generally Western orientation have earned him a reputation that attracts former bureaucrats to his side, makes him more acceptable to the United States, and in the opinion of some, renders him a better candidate to compromise with the Soviet government on the restoration of an independent Afghanistan. ... Gaillani apparently views the former monarch as capable of attracting segments of the peasantry within the country, the refugees and moderate Islamic countries to his Islamic alliance camp. ${ }^{\prime 30}$

The Shiite leadership in Afghanistan has always looked to Iran for moral, ethical and religious guidance. Shiite clerics and students studied at religious schools in Mashhad and Qum. Upon their return to Afghanistan they began to disseminate radical religious ideas in order to transform the status quo. When clerics seized power in Iran in 1979 the Iranian regime provided the Shiite Hazaras with political, economic and military support in their struggle for the establishment of a theocratic regime. Iran's policy toward the Soviet occupation has been characterized as follows:

"The Iranians consider the Soviet invasion of Afghanistan the most favorable situation for the consolidation and extension of their influence in the country. In the beginning they decided to help all the Hazara groups without discrimination. When it did not work according to their wishes, they changed their policy and decided to federate the groups under the umbrella of one organization, Nasr, a party which they found the best organized. Nasr ... is the amalgamation of two parties. ... But last year (1982) the Iranians sent a delegation to Hazarajat in order to investigate the activities of Nasr and to see how their military and financial help was being used. The Iranians were deeply disappointed and convinced that it was impossible to accomplish anything with the Afghanistani parties. Then they decided to operate through their own Iranian party inside Afghanistan and created the Sepah-e-Pasdaran; it has the same structure and the same organization as the Iranian Islamic Revolutionary Party, only the members are Afghanistanis."31

The popularity of Khomeini among the Shiites in Afghanistan expanded to the extent that "in Hazarajat, the portrait of Khomeini is part of the decor. The Shiites display it ostentatiously everywhere, over the doorways of their huts and in the bazaars, inns and public buildings" ${ }^{32}$ When Khomeini seized power in Iran most Shiites slaughtered the fatted calf in honor of the

30 Eden Naby, "The Changing Role of Islam as a Unifying Force in Afghanistan", in The State, Religion and Ethnic Politics: Afghanistan, Iran, Pakistan (Syracuse: Syracuse University Press, 1986), pp. 136-37

31 Account by French Reporter Jean-Jose Puig in Afghan Information Center Monthly Bulletin (Peshawar: Pakistan) 32-33 (November-December 1983), pp. 27-28

32 Le Monde, 28-30 December 1983, in JPRS Near East/South Asia Report, 7 February 1984, p. 78 
second coming of the Imam. The Shiite parties ardently supported the political philosophy of Khomeini and adhered to his famous dictum -neither East nor West but Islam. Khomeini's clout and Iran's influence on the Shiites in Afghanistan began to decline when the Hazara leader, the late Abdul Ali Mazari, began to propagate Hazara nationalism. This situation provoked the Iranian leadership and compelled them to support a faction of the Shiites headed by Mohammad Akbari, thereby causing further disunity within the Hazara community. There are twenty or more Shiite organizations, the more prominent include ${ }^{33}$ :

- Shura-e-Itifaq (Council of the Union)

Place \& Date of Formation: Bamiyan, Afghanistan, 1979

Head: Sayed Ali Behishti

Ideology: Traditional Islam

Composition: 1,000 staff; 2,000 partisans

Main Front Commander: Mohammad Hasan, known as Sayed Jaglan

Bases of operation: Bamiyan, Ghazni, and Balkh

- Harakat-e-Islami (Islamic Movement)

Place \& Date of Formation: Qum, Iran, 1979

Head: Mohammad Asif Mohsini

Ideology: Traditional Islam

Composition: 200 staff; 3,000 partisans

Main Front Commander: Muhammad Anwari

Bases of operation: Wardak, Qandahar, Bamiyan, Parwan, Kabul and Samangan provinces

- Sazman-e-Mujahidin-e-Mustazafin (Organization of Warriors of the Dispossessed)

Place \& Date of Formation: Bamiyan, Afghanistan, 1979

Head: Joint Council

Ideology: Militant \& Political

Bases of operation: Bamiyan.

- Sazman-e-Nasr (Victory Organization)

Place \& Date of Formation: Qum, Iran, 1979

33 Compiled from literature published by Hazaras political parties, and interviews with Hazara intellectuals in exile. 
Head: Council of "four" persons

Ideology: Islamic Fundamentalism

Composition: 1,500 staff; $.4,000$ partisans

Bases of operation: Ghor, Bamiyan, Wardak, Parwan, Ghazni, Balkh, and Kabul provinces

- Sepah-e-Pasdaran (Revolutionary Guard Corps)

Place \& Date of Formation: Qum, Iran, 1981

Head: Mohammad Akbari

Ideology: Islamic Fundamentalism

Composition: 1,500 staff; 2,000 partisans

Bases of operation: Ghor, Helmand, Bamiyan, Ghazni, and Parwan provinces

- Hizbullah (Party of God)

Place \& Date of Formation: Qum, Iran, 1981

Head: Shaikh Wusoqi

Main Commander: Qari Ali Ahmad Darwazi known as Qari Yakdasta Ideology: Islamic Fundamentalism

Composition: 1,000 staff; 2,000 partisans

Bases of operation: Ghor, Herat and Helmand provinces

- Hizb-e-Wahdat (Unity Party)

Date of Formation: 1988

Head: Karim Khalili succeeded Abdul Ali Mazari

Ideology: Moderate Islam \& Hazara Nationalism

Composition: Sazman-e-Nasr, Sepah-e-Pasdaran, Hizbullah, Dawat (Invitation), Nahzat (Progress), Nayro-e-Islam (Islamic Strength), Jabha-e-Mutahid (United Front), Shura-e-Itifaq, Sazman-e-Mujahidin-e-Mustazafin and Harakat-e-Islami.

The Ismailis constitute a minority within the Shiites and pledge their allegiance to Karim Aga Khan, the 49th and present Imam of the community world-wide. Ismailis supported the Soviet-backed government because in the past both the Sunnis and the Shiites have suppressed them and treated them as heretics. However, a member of the revolutionary Ismaili elite, Captain Noor Mohammad of Shibar district, Bamiyan and the influential Ismaili tribal chief, Sayed Manucher of Kayan district, Baghlan province, joined the anti-government resistance movement. The former was assassi- 
nated by a rival Ismaili group and the latter forged an alliance with the pro-government Ismaili chief, Mansoor Naderi. ${ }^{34}$

A number of Shiite parties which received aid from Tehran supported Iran in its war against Iraq and actively participated in the defence of Iran. The Islamists are divided not only by their philosophical interpretation of the Islamic doctrine and political agenda regarding the future of the country but also by tribal and ethnic differences which caused them to treat each other with suspicion and fight each other. A copy of a secret document of Hikmatyar's Hizb-e-Islami is vivid evidence of the internecine struggle among the Islamists. The document reads:

'Members of the Hizb-e-Islami while fighting against the 'Red Satan' must corner, isolate, and even eliminate the other rebel groups in order to project the image of Hizb-e-Islami. If you consider yourselves weaker militarily to act against them (other groups of the alliance) then the Commander can inform the occupant Russians or their dependents about domiciles of alien guerrillas." 35

The Islamists did not offer any solution to the question of land distribution, national oppression and, in particular, women's status and rights. They reinforced wearing of the veil and Islamic dress for women and did not let them take part in the resistance, outdoor activities, or work in the presence of men. Moderates within the Sunnis, Shiites and Ismailis supported the rights of women to education and work outside the home and even their participation in public political activities. Fatima Gillani represented Afghanistani women in meetings and conferences overseas, despite having nothing in common with dispossessed and oppressed women of lower social classes. Women have more representation in Hizb-e-Wahdat, with nine females admitted to its central council. Dr. Sima Samar, a member of the central council of the party, runs the Shuhada Clinic in Quetta, Pakistan, is an activist for women's emancipation and empowerment and represented Hizb-e-Wahdat in several public forums abroad. When the Sovietbacked government in Kabul declared a general amnesty and called upon refugees to return, a significant number expressed their willingness to do so before the Soviet withdrawal was completed, but Islamists opposed their return, "fearing that their own influence will decline once refugees return to their traditional villages and district environment." 36

Hafizullah Emadi, "Minority Group Politics: The Role of Ismailis in Afghanistan's Politics". Central Asian Survey, 12:3 (1993):379-392. Also see. Hafizullah Emadi, "Politics of Transformation and Ismailis in Gorno-Badakhshan, Tajikistan". Internationales Asienforum, 29:1\&2 (May 1998), pp. 5-22

35

General Union of Democratic Students and Patriotic Afghans (GUDSPA), Afghanistan-eAzad [Independent Afghanistan] (San Francisco) 16 (November-December 1982), p. 9

36

Christian Science Monitor 24 May 1988, p. 16 
The Soviet leadership regarded continued Soviet involvement in Afghanistan as a bleeding wound and wanted to find ways to withdraw its troops. To this end the Soviets encouraged the Kabul regime to expand its social base of support by coopting non-party members and initiating reforms and glasnost. This policy led to the dismissal of Karmal in May 1986 and the appointment of Najibullah, chief of the notorious state security apparatus, as the new head of state. Najibullah launched new policies aimed at portraying his regime as independent of the Soviet Union. He appointed non-party members to key government posts, permitted the formation of independent civic organizations and revoked some earlier decrees on land reform bills. The Geneva Accord signed by Pakistan and Afghanistan, and endorsed by the United States and the Soviet Union, paved the road for Soviets to withdraw their troops, and the last Soviet regiment left the country in February 1989. After the Soviet troop withdrawal the Kabul regime managed to survive and made serious efforts toward national reconciliation. In 1990 the ruling party also changed its name from Hizb-e-Demokratik Khalq to Hizb-e-Watan (Party of the Homeland) and permitted opposition civic and political organizations to conduct their business without government interference. Continued armed struggle against the Kabul regime after the Soviet troop withdrawal and the United Nations mediation persuaded Najibullah to agree to the transfer of power to a transitional government by exiled Islamists. In 1992 Najibullah resigned and, on his way to the airport for India, his opponents prevented him from leaving the country, forcing him to seek refuge at the United Nations office in Kabul.

\section{The Islamic State and the Civil War}

In April 1992 Sebghatullah Mujaddai became head of the transitional state in Kabul until he was succeeded by Burhanuddin Rabbani of Jamiat-eIslami on 30 August 1992. The Rabbani government immediately embarked upon Islamization of the country. Instead of paying greater attention to rehabilitate and re-establish security and stability it began to prescribe an Islamic dress code for women and dismissed female TV anchorpersons. A year later, on 27 August 1993, the Government Office of Research and Decrees of the Supreme Court issued an order to government agencies and officials to dismiss all female employees from their posts and close down schools for girls, as schools are considered to be whorehouses and centers of adultery and fornication. The decree reads:

"Women need not leave their homes at all, unless absolutely necessary, in which case, they are to cover themselves completely; are not to wear at- 
tractive clothing and decorative accessories; do not wear perfume; their jewelry must not make any noise; they are not to walk gracefully or with pride and in the middle of the sidewalk; are not to talk to strangers; are not to speak loudly or laugh in public; and they must always ask their husbands' permission to leave home."37

It is the second time in the history of Afghanistan that the Tajiks seized state power but each time they failed to sustain it. Their failure is largely due to a myopic religio-political strategy based on the false notion that reliance on modern weaponry would ensure their continued domination. The Tajik dominated government of Rabbani and Ahmad Shah Masoud did not support power-sharing to broaden the social base of the newly founded state. Consolidation of Tajik domination backfired and compelled other ethnic communities, Hazaras, Uzbeks, Turkmens, and the Pushtuns to oppose the Kabul regime. The ruling party also used every means at its disposal to pit one ethnic community against the other, believing that such a policy would ensure its survival. Defense Minister Masoud instructed the security department to fuel ethnic conflict among the Hazaras and Pushtuns. A facsimile of the letter reads:

"Considering the progress of your work, you are instructed to authorize every department of the National Security to intensify the war between Hizb-e-Wahdat and Hizb-e-Harakat on the basis of ethnic cleansing between Hazaras and Pushtuns to the extent that its effects must incite hostilities among inhabitants of central and northern parts of Afghanistan either in the form of Shiite and Sunni differences or as hostilities between the Hazaras and Pushtuns which would be a sufficient ground for preoccupation of future military fronts.",38

The implementation of such a policy paved the way to wide spread ethnic cleansing, looting of public property and destruction of economic, social, administrative and civic enterprises. Pro-Rabbani and Masoud Tajiks of Panjshir have been accused of being the main culprits who make their fortunes by looting private and public properties upon seizing power in Kabul. The struggle for power and over booty in Kabul led various Islamic groups to engage in a brutal war against each other, taking men and women hostage, raping and mutilating women and girls, and killing innocent people. Their hostility toward the detainees ranged from gouging their eyes out and cutting off their noses to immolation. The brutality of the Rabbani regime towards the Hazaras in Kabul in the March 1995 military

37 Fatwai-e-Sharia-e-Satr wa Hijab, Kabul 27 August 1993. Cited in Helena Malikyar, "Development of Family Law in Afghanistan: The roles of the Hanifi Madhhab, customary practices and power politics". Central Asian Survey 16:3 (1997), p. 396

38 Nama-e-Khabari Wahdat [Wahdat Newsletter] 32 (30 September 1994), p. 5 
assault and its subsequent war against this ethnic group has been characterized by Amnesty International:

"This was apparently in retaliation for bomb attacks on Kabul allegedly by the forces of Hizb-e-Wahdat and the Taliban. Hizb-e-Wahdat defenses had broken, their positions had been abandoned and according to all reports, there were no signs of military assistance. Nevertheless, the troops opened fire on the defenseless population. On 12 March President Rabbani's soldiers reportedly rampaged through Kart-e-Seh, looting houses, killing and beating unarmed civilians and raping Hazara women ... One family interviewed by a foreign journalist ... said President Rabbani's soldiers had told them they wanted to 'drink the blood of the Hazaras'. Medical workers in the area confirmed at the time at least six incidents of rape and two attempted rapes, but believed the actual number was much higher.",39

Scores of prisoners from the Hazara ethnic group have reportedly been beaten for a long period in the Qala-e-Haider Khan detention center in Paghman province, which is run by Ittehad-e-Islami. The prisoners have included women who had reportedly been abducted by the group's guards in order to be sold into prostitution or to be given as 'gifts' to financial supporters. ${ }^{40}$

Mediation by Pakistan, Iran and other countries to reconcile the warring factions did not end the cycle of ferocious ethnic cleansing nor was the signing of a peace protocol by the Islamists in Mecca, Saudi Arabia, honored. Rabbani and Masoud accused Pakistan of interfering in Afghanistan's internal affairs and strengthening the country's ties with Iran, India, and Russia. Pakistan, which supported the Pushtun drive for political domination of Afghanistan in order to stave off the secessionist tendencies of its own Pushtuns in the North West Frontier Province (NWFP) ${ }^{41}$ was not happy with the Tajik domination of Kabul and its hostility toward Pakistan. To this end it supported the Talibans and provided them with financial and military support to seize power.

The Taliban movement, which is predominately Pushtun in its rank and file, is comprised mostly of students who studied religion in madrasas (religious schools) in Pakistan. They are strongly influenced by the teachings of Mawlavi Fazl al-Rahman, head of Jamiat-e-Ulama-e-Islami in Pakistan. The Taliban main slogan was to put an end to the fratricidal war

39 Amnesty International, Afghanistan: International Responsibility for Human Rights Disaster (New York: Amnesty International, 1995), p. 35, pp.64-65

40 op.cit., p. 66

41 Hafizullah Emadi, "A Historical Perspective of the Durand Line and the Future of Afghanistan-Pakistan Relations", World Review 30:3 (March 1991), pp. 5-12 
that destroyed the country and establish peace and stability. Their campaign started in 1994 with the seizure of Qandahar province and establishment of their headquarters there. They gradually expanded their rule by conquering more territories, defeating Ismail Khan, governor of Herat, who was despised by his subjects but supported by Iranian revolutionary guard corps in Mashhad. After capturing the city of Jalalabad from Haji Abdul Qadir forces and facing little or no resistance, they established their domination over Laghman and Kunar provinces. When the Taliban forces marched toward Kabul, Hikmatyar forces in the Sorobi district, Kabul, abandoned their position, enabling the former to seize power in Kabul on 26 September 1996. Rabbani and Masoud, who lost popular support, fled to the north and established their base there. The Taliban militias entered the United Nations office, arrested Najibullah and his brother Shahpur Ahmadzai, who served as his security chief. After killing them the Taliban dragged their bodies through the streets and hanged them in a public square in Kabul. They established a six-member council headed by a cleric known as Mullah Mohammed Rabbani. The fall of Kabul to the Taliban and their march northward forced the ousted regime of Rabbani to forge an alliance with Junbish-e-Milli Islami of Abdul Rashid Dostam and Hizb-eWahdat headed by Karim Khalili.

After consolidating their hold in Kabul the Kabul based Radio Sharia announced on 28 September 1996 that according to orders of the Amir alMuminin (commander of the faithful), Mullah Mohammad Omar, women are forbidden to work outside the home and girls are not allowed to go to school. The decree outraged educated women throughout the country and on 21 December 1996 women in Herat organized a public rally defying the Taliban order and demanding their right to work and education. As a result twenty women were arrested and forty were wounded. Radio Sharia announced that 250 women were beaten for not observing the Islamic dress code. The Taliban version of Islam demands that men must grow thick beards, people must refrain from playing cards, listening to music, keeping pigeons and flying kites, and people who commit robbery will have their hand amputated and adulterers must be publicly flogged and stoned to death. To implement their strict version of Islamic laws the Taliban unleashed an army of enforcers throughout territories under their control. The Taliban reign coincided with rising inflation. Between August 1996 and January 1997 the price of bread rose from 500 to 1000 Afghanis, seven kilos of flour from 22,000 to 38,000 , seven kilos of fire wood from 5,000 to 7,000 and a litre of petrol from 25,000 to 45,000 Afghanis (1 US $\$=15,000$ which rose to 45,000 Afghanis five months later). Government employees were paid $15,000(\$ 6.50)$ per month and sometimes the payment was 
delayed. 150,000 women employed prior to the Taliban ascent to power are now forced to stay home.

The Taliban continued their advance toward the north. On 24 May 1997 Abdul Malik, an Uzbek army officer who served as Dostam's field commander, defected to the Taliban and marched into Mazar-e-Sharif. Dostam fled to Uzbekistan and finally to Turkey; Rabbani reportedly sought refuge in Tajikistan. Malik's defection was intended to avenge the death of his brother Rasul Pahlawan and some of his dead relatives. The next day the Taliban soldiers moved into Mazar-e-Sharif, trying to disarm supporters of Hizb-e-Wahdat and other armed groups. Supported by Hizb-e-Wahdat Malik fought the Taliban, inflicting heavy casualties on them and forcing them to evacuate their forces from Mazar-e-Sharif. After ousting Dostam from the leadership Malik delegated important military tasks to Jamiat-eIslami. Hizb-e-Wahdat and the Uzbeks regarded Malik as a traitor who betrayed their cause and sought ways to restore Dostam. With the help of Hizb-e-Wahdat Dostam returned to Mazar-e-Sharif in September 1997, fought Malik and forced him to leave the country.

During a military assault on 8 August 1998 on Mazar-e-Sharif the Taliban defeated supporters of Dostam and those of Hizb-e-Wahdat and seized control of the city. Reports indicate the Taliban army massacred and executed 2,000 - 5,000 civilians who were mainly Shiite Hazaras. ${ }^{42}$ The Taliban offensive also claimed the lives of nine Iranians provoking the Iranian leadership to mobilize a large number of elite troops for one month military exercise in an effort to compel the Taliban administration to release Iranian hostages and extradite those who were responsible for killing Iranian civilians. After consolidating their base in Mazar-e-Sharif the Taliban launched an assault on Kayan district, Baghlan province, forcing Mansoor Naderi, chief of the Ismaili community to seek refuge to Uzbekistan. The Taliban also attached Hizb-e-Wahdat's stronghold in Bamiyan, defeated Hizb-e-Wahdat supporters and established their administrative apparatus in Bamiyan.

Despite Taliban's conquest of more territories in central and northern parts of the country and mediation by the United Nations to bring warlords to work toward restoration of peace and stability, civil war continues unabated causing further devastation and claiming more innocent lives.

42 Kenneth J. Cooper, "Ethnic Hatred Led to Massacre by Taliban in August", The Seattle Times, November 28, 1998, A-3 


\section{Conclusion}

Political Islamists in Afghanistan modelled themselves on the nation state, whose very existence they condemn and oppose as unislamic vis-à-vis the Umma, the community of believers. Their failure is both ideological and ethical. Ideologically the parties placed great stress on leadership but not on political, social and economic policies for rebuilding the country. They stressed Islamization of an already Muslim society rather than paying greater attention to the reconstruction of the country. Their Islamization strategies did not go beyond mandating the veil for women, beards for men and the destruction of every type of recreational activity. Ethically, leaders of the Islamists claimed to follow the Prophet's example of leadership style, even though each amir had his personal weakness. They engaged in building a personality cult which paved the way for a greater struggle for power and the right to rule the country among them.

The Islamists were unable to win the hearts and minds of the dispossessed social strata in the urban areas and peasants and farmers in the countryside who had nothing to gain from the establishment of an Islamic state but continued misery, suffering and bloodshed. Their policy program and its articulation were entirely alien to both the common people and the modern educated elite. Divorced from public support, the Islamists relied on their lethal military arsenal and added fuel to the flames of communal politics and ethnic chauvinism in order to maintain and defend their bloody fiefdom.

To rebuild the country Muslims of all denomtinations must resolve their philosophical differences on the interpretation of Islamic doctrine. Their hostility to each other stems from lack of understanding of each other's school of thought and lack of tolerance of differences. They could establish educational programs to familiarize members of each others community and the younger generation with the fundamentals of their respective schools of thought. Broad minded and trained Muslims can play a crucial role in the process of uniting and rebuilding the country. An emerging government based on public consensus must allow ethnic communities complete autonomy in conducting their social, religious, cultural and political affairs as a prerequisite for a united Afghanistan. Such a policy would help ensure the country's territorial integrity and political independence and would pave the road for rehabilitation and reconstruction in the twenty-first century. 